\title{
17. Lands of Fire and Ice: From Hi-Story to History in the Lands of Fire and Ice-Our Stories and Embodiment as Indigenous in a Colonised Hemisphere
}

\author{
May-Britt Öhman and Frances Wyld
}

This article brings together two Indigenous scholars who have come to better know their Indigenous history as they story it alongside their work as historians and academics. We find that the historical landscape changes when family history is better understood: time and space become embodied, history becomes personal. Sámi scholar May-Britt Öhman speaks of singing to the hillside in a 'Sound of Music' style, and then feeling forced to break out of song and into yoik. ${ }^{1}$ Similarly, Aboriginal Australian scholar Frances Wyld writes about her connection to land and family history, including a visit to desert Australia where she no longer saw a world of silos, but of solace. Through embodiment comes a new identity, shared and understood. As scholars understanding the powerladen binaries of colonised and coloniser, writing at the intersection of personal and public using ego-histoires, we find shared methodologies to tell stories of the self inhabiting lands of fire and ice. Applying ego-histoire, we argue for a new version of history as academic discipline: a discipline which includes the Indigenous peoples' embodied vision and experiences; a history discipline which challenges the coloniser's current Hi-Story, within which Indigenous peoples are made the other, the exotic, primitive and invisible 'vanishing race'; a history which empowers and strengthens ourselves as scholars and at the same time provides our students (Indigenous as well as non-Indigenous) with a history which takes into account Indigenous peoples visions, experiences and stories.

\section{Prelude}

Öhman and Wyld are from two different countries and met in a third country: at the 2011 Native American and Indigenous Studies Association conference in

\footnotetext{
1 Yoik is traditional Sámi singing/recital where the story being told is an inherent part of the music produced. Identified by the Swedish state church as heathen, the tradition has disappeared in many families, while kept secret in others. With Sámi cultural revitalisation taking place over the last two decades, the tradition has started to regain force.
} 
the USA. They exchanged contact details with the plan, which many conference delegates have, to collaborate at a future date. Ongoing communication between these two scholars resulted in Wyld travelling to Sweden to attend the First Uppsala Supradisciplinary Feminist Technoscience Symposium in 2011, which was convened by Öhman. They went on to collaborate further in producing this chapter. In 2012, Wyld participated in the second symposium via Skype, presenting the following story with Öhman. The two met again in 2013 when Öhman held the Third Uppsala Supradisciplinary Feminist Technoscience Symposium, which had now grown to a week-long event with a strong Indigenous focus attracting scholars from all over the world. Wyld hopes to return to Sweden again to visit Öhman's ancestral home and see the Northern Lights, and also hopes to be able to host Öhman in Australia.

Both storytellers have Indigenous heritage and work in academia. We speak from a voice that is created in a hybrid space, joining the lands of Sápmi and Australia, working across disciplines, including words of both colonised and coloniser. But we follow a tradition of storytelling, a narrative evident in many Indigenous cultures and used as a teaching tool. It is also a device recognised by historians in the use of ego-histoire. Popkins states: 'Historian-autobiographers are uniquely placed to show that the historian's subjectivity is not arbitrary but rather a result of choices among a historically defined range of possibilities. (Popkin 1996, pp. 1166-1167). We choose to tell our stories.

May-Britt: I want to start with a story of my first embodied meeting with yoik. In my family, the Sámi heritage was shamed away; language, religion and cultural traditions washed away by a state policy of assimilation to a SwedishEuropean positivistic industrial modernity. Yoik was proclaimed by the church as blasphemous. Forest Sámi were judged to not be real Sámi-the real Sámi were the Mountain reindeer herding Sámi. My family was supposed to become Swedish, modern. My mother fiercely denied any Sámi heritage. It was only at the age of 42 that I was told that we were Sámi (Öhman, 2010). Aged 23, in the fall of 1990, just before leaving my hometown Luleå to start my studies in the history of science and ideas at Uppsala University, I visited the mountain Loktaćohkka/Låktatjåkka (350 kilometres from Luleå towards Narvik) with friends. The air was so fresh, the mountain so majestic. I wanted to sing to it. Trained to sing the European way, in a church choir, I started singing, 'The hills are alive, with the sound of music'. But after the first tones I had to stop. I felt like I was swearing loudly in a church and the mountain was hushing me. I felt like the only way of singing to the mountain was through yoiking. I had never learnt how to yoik. In my family no tradition of yoiking was ever passed on to me. Still, I did yoik, a low almost mumbling respectful vuolle. ${ }^{2}$ Not to the mountain. I actually yoiked the mountain and the view. It felt right. It felt good.

2 'Yoik' means 'to sing'. 'Vuolle' is the song/narrative. (See Stoor, 2007). 
The memory and feeling has followed me ever since. But not until this very moment have I mentioned this event to anyone. I yoik my memory of this event now, to you, the reader.

Frances: The autobiographical element for me in this chapter is the storying of my connection to land and the journey back into my Aboriginal history, in particular my reactions to my family story, an autobiography written by my aunt, Doris Pilkington Garimara, which is being used within the curriculum of history teaching (Garimara1996). My autobiographical moments may seem fragmented and this is because the connection is fragmented. The removal of Aboriginal children in Australia from their families has created generations of people removed from culture and identity. If I had grown up within Aboriginal culture I would have a matriarchy of elders to call upon for wisdom. I can still choose to practise this within my workplace, within a colonised space. I can turn to the work of senior Aboriginal woman and academic Irene Watson who discusses colonisation and the rejected law of terra nullius:

Franz Fanon saw the 'smoking ashes of a burnt-down house after the fire has been put out (but) which still threatened to burst into flames again'. I ask the reader: in relation to Australia, has there even been an attempt to put the fire out. Or have we witnessed merely the illusion of change? (Watson 2007, p. 17).

The fire still burns. There is somehow still a connection for me to my Aboriginal ancestry even though I am also tied to the old imperialist structures.

\section{Introduction}

The land is a story place; its history is open to the gaze of those who can see. We share stories, we travel from hemisphere to hemisphere, returning to our own country with new perspectives, new ways to construct the stories of our pasts. The etymological definition of history can be placed within two languages: in old French we have the word estoire or estorie meaning 'chronicle, history or story', and in Greek the word historia, meaning 'a learning or knowing by inquiry; an account of one's inquiry, history, record, narrative'. For Indigenous peoples this connection to story is important, for we are storytellers. But our worldview differs from that of what is commonly perceived as the objective, disciplined history, predominantly written by the colonisers. This mode of establishing history - or as we prefer to call it 'Hi-Story' — has not been kind to us. ${ }^{3}$

3 In feminist writing, History has been challenged as 'His story': history being produced from a male perspective. The concept of 'Herstory' was introduced in the 1970s to emphasise the role of women or history told from a woman's point of view, as well as a piece of historical writing by or about women. 
When searching for the 'pure' definition of Indigenous Peoples, as Maori scholar Linda Tuhiwai Smith observes, the 'othering' by historians and anthropologists is seen as a desire to know and define the 'native' (Smith 2005). This desire of the dominant culture fixed Indigenous identities to the past, disallowing the development and change afforded to modernist cultures. Binaries developed and doors closed to the pursuit of a sharing of knowledge as inquiry through storytelling. This paper will examine a pathway across the disciplines made possible by ego-histoire; the situating of culture that evolves, of myth used to explain everyday life, of knowledge embodied and remembered. The land is a history place, whether it is the ice-scapes inhabited by the Indigenous people of the Arctic, or the desert-scapes of the Indigenous people who inhabit lands the colour of fire in Australia.

\section{Locating Ego-Histoire Alongside Yoiking and Indigenous Storytelling}

Starting with the memory of yoiking the mountain, May-Britt raises a fundamental issue in regard to history - as opposed to Hi-Story-when evoking this integral part of Sámi culture, expression, history, and storytelling, which, despite recent efforts, is still far from being recognised within the social sciences and humanities (see Stoor 2007). First of all, it tells about the yoiking being silenced because it is considered blasphemous by the colonising state church, leading to an eradication of this tradition, and an important part of the Sámi culture. But here May-Britt shows how it comes back to her, as a force from the mountain, and from within. While such embodied encounters are not recognised within current Hi-Story, it is recognised as part of the Sámi culture, and could be part of a new version of history in which Indigenous perspectives are voiced. In this way, yoiking could be considered to be playing a role as ego-histoire. The yoiking can be described as the creation of a picture or photo expressed in phrases and song. Sámi author Johan Turi wrote in 1910:

Sámi singing is called joiking. It is a practice for recalling other people. Some are recalled with hate, and some with love, and some are recalled with sorrow. And sometimes such songs concern lands or animals: the wolf, and the reindeer, or wild reindeer. (Turi 2011, p. 161).

In 2007, the Swedish Sámi yoik artist and Indigenous scholar Krister Stoor published his dissertation, 'Yoik Tales: A study of the narrative characteristics of Sámi yoik' (Stoor 2007). Stoor argues that the yoik tradition is not just music or song, and that the story told is of equal importance: 'The way of presenting a vuolle is also a part of the yoik tradition and one has to consider both the spoken and the sung messages in order to understand what the performer means. 
In short, yoik must be recognised as verbal art or storytelling' (Stoor 2007, p. 177). Another currently active Sámi yoiker and scholar of law, the Norwegian Ande Somby, also discusses yoik from a social science perspective. He states that there is a difference between yoiking and other European/western musical tradition. You don't yoik about something. You yoik something or someone, the yoiker becoming an integral part of what he or she is yoiking: 'In a manner of speaking, a yoik has no object. In fact, it is altogether impossible to envision yoik in terms of subject and object' (Somby 1996, p. 1). Yoiking can thus be considered a form of production of history, ultimately challenging and possibly overthrowing the proclaimed objectivity criteria of Hi-Story, in which only documents and recorded stories collected and dissected by colonisers and power-holders in society are recognised (see Haraway 1991b).

Storytelling is a tradition within many Indigenous cultures (Archibald 2008; Martin 2008; Kovach 2010); it is a way to pass on a worldview as a respectful process between storyteller and listener. Traditions are built upon this exchange and the stories are valued. With the introduction of the written word through colonisation and the developed technologies that go with writing, many Indigenous people chose to write down their stories for publication. One of the most popular genres has been autobiography or life writing, as stated by Moreton-Robinson in Talkin' Up to the White Woman (Moreton-Robinson 2009). Smith also discusses this theme:

Indigenous peoples want to tell our own stories, write our own versions, in our own ways, for our own purposes. It is not simply about giving an oral account or genealogical naming of the land and the events that raged over it, but a very powerful need to give testimony to and restore a spirit, to bring back into existence a world fragmented and dying (Smith 1999, p. 28).

Smith speaks of a desire to be self-naming, and of shifting identities and hybridities (Smith 2005). Hybrid space recognises the legacy of narratives from two sides of the world. In speaking of his own hybrid space, Indigenous scholar Ian Anderson found that by listening to the stories of his people he had become a 'voyeur of [his] own history' (Anderson 2003, p. 44). As Indigenous peoples we can become disconnected from our own stories because they are used for education or research purposes, or are written by the coloniser. As Indigenous people working in the world of the coloniser, there is a danger that we can forget to follow the protocols of an Indigenous worldview. The use of preludes as introductions and life-writing as story telling, and by working alongside respectful academics using ego-histoire can remedy this.

The term hybrid is controversial, and we use it in the way that Donna Haraway uses her Cyborg Manifesto (Haraway 1991a): it is blasphemous. We use it in 
recognition that our work is a meeting of our biological and cultural selves. It is a hybrid space connected to sites of memory, 'enveloped in a Möbius strip of the collective and the individual, the sacred and the profane, the immutable and the mobile' (Nora 1989, p. 19).

It is a challenge to develop a voice that can speak autobiographically, to develop the life writing voice of the self, within a field that asks for an objective voice based on written sources, collected by the colonisers in state or church-supported archives. Both our cultures have honoured themselves in not leaving traces, or marks behind. There are no or very few documents left showing our ancestors' point of view, whereas there are massive amounts of information collected by outsiders visiting, colonising and dissecting our ancestors lands and lives. So how then to write our own history? In this paper we speak of an Indigenous worldview, an ontology and epistemology documented by a growing number of Indigenous academics (for example, Martin 2008; Arbon 2008).

To make this hybrid space that mixes history and life writing, to argue that this voice is important, is to look back in time and to be connected to place, to speak not as a generalisation but as the self. Smith warns that 'social science cannot simply develop grand narratives of the silenced without including the voices and understandings of marginalised and silenced communities' (Smith 2005, p. 91). We create a hybrid space to look back in time to see how the subject is created and think that, like Nora, we make history that will one day require a chapter in a book. It is a time when we challenge universities to situate Indigenous studies within their departments where the teaching of history is still very important. As Indigenous people we challenge all historians to include the subjectivity into this scholarship. To us, what happened and still happens through colonisation is personal, and it is a matter of life and deathof both cultural and physical survival and mental wellbeing. In Australia this subjectivity has been questioned, declared a distortion, as stated by Frances Peters-Little, who says that 'the whole basis for wanting to become a historian in the first instance comes from a place deep inside me, from a desire to understand, acknowledge and come to terms with what has happened to my ancestors, my culture and my land' (Peters-Little 2010, p. 2).

A story wants to be told here, one that speaks to the issues of who writes history and why the personal can invade the academic space. Life-writing invades the academic format; the Indigenous worldview cannot be kept out. We tell our own stories.

Frances: When I think of speaking back to the historian who has spoken about my family in public, I think not in academic arguments, I think of a day in time. It was the day of Australia's National Apology to the Stolen Generations. I chose not to attend one of the public events where it would be televised, I chose to 
teach. I gave myself no time for reflection as I heard the words from our Prime Minister, I drove past the place of my own birth, a place far from my peoples' cultural home because child removal practices had affected the generations before and my birth was elsewhere, in this suburb that I drive through. My lecture would be on Aboriginal history in education; it was passionate. I held in my hands the newspaper that was using images of the film made from the biography of my grandmother. I spoke about the historians who would call this story a myth. The last activity of the teaching day was a role play. Halfway through I lost my voice. A student stepped forward to read the prepared script and I knew then that spending the day teaching instead of attending the public events was the right choice. On that day, I chose to listen to the apology on the radio in my car, but I also chose to speak, to not necessarily be amongst the masses making history, but to tell a history.

Frances Peters-Little as Aboriginal woman and historian recognises that the discussion on remaining dispassionate in her work is a luxury she has 'not been afforded'; for her and other Aboriginal people, 'the past and present are linked indissolubly through place and belonging' (Peters-Little 2010, p. 2). It is timely for historians to place themselves in their work through life-writing and autobiography. Connections to the past must be maintained to continue the work of decolonising academic spaces.

\section{Colonised Lands of Ice and Fire}

We write about lands storied as extremes, as elements in opposition to each other. The land inhabited by the Sámi people is known as Sápmi and shares the historical title of terra nullius with their Australian Aboriginal cousins. Sápmi extends across four current nation states: Norway, Sweden, Finland and Russia. This view of Sápmi is a colonising one, whereas a gaze provided by Sámi people shows you a land that has no borders, a map seen from the top of the world, extending over the Arctic and sub-Arctic regions of the Scandinavian peninsula and the Kola peninsula (Öhman 2007). This colonising gaze was also extended to Australia, now seen as one country, not as it was over 200 years ago: a patchwork of language groups similar to the continent of modern Europe. To story these descriptions we see the art of cartography moving in opposite directions, the scattering of one Indigenous group and the homogenising of another. If the land could story itself it would not speak as a cartographer or as a study in elemental oppositions. The land would speak of seasons, of lands with no boundaries. As we write it is winter in the land of fire and summer in the land of ice. And they were not the land of no-one prior to colonisation. 
May-Britt: I learnt in school, and it is still taught to school children, that the Scandinavian Peninsula was completely covered by an ice-cover up to three kilometres thick, leaving no possibility for human or non-human life in this area. We learn that 10,000 years ago the ice started melting away and that today we can find traces of the first human settlers who migrated here. Archaeological investigations are plentiful in Sápmi. They have been conducted throughout the twentieth century, partly financed by the Swedish state power company (Vattenfall) obliged to finance archaeological investigations before inundating our lands and damming our rivers (Öhman, 2007). Somehow, for some reason, it is very important to find out what the Sámi are. Why so different from the Swedes? The archaeologist C-G Ojala, himself a person with roots in this region with its mixed groups of Sámi, Finns and Swedes, writes:

The origin of the Sámi people has been one especially consistent theme in the history of scientific interest in the Sámi. At times, it has been the dominant theme, overshadowing other ways of studying and understanding the Sámi past. Throughout the centuries, many ideas and views on the origin of the Sami have been put forward by different researchers - Lappologists, historians, archaeologists, linguists and anthropologists - who have connected various older sources and new findings in their search for origins. Moreover, the origin of the Sámi has very often been presented as being a great mystery and a riddle waiting to be solved (Ojala 2009, p. 11).

Who was here first, after the ice melted away? The question of who the first human inhabitants were has become a controversial political issue, with archaeologists called to provide testimonies in courts over disputes of traditional land rights between Sámi reindeer herders and other local inhabitants who have been-despite probably being related to one another-categorised as Swedes and having bought or inherited land areas (see Ojala, 2009, p. 155). Searching in literature for information so that I can understand and communicate how this land of ice would have looked, I find something revolutionary. Well, it is a revolutionary insight to me. I was told and had learnt to believe that nothing could have lived here with this immense ice-cover, that my ancestors had to migrate here at some point after the ice-age. But in March 2012 a group of researchers at my own university published an article stating that trees lived here: 'Our findings imply that conifer trees survived in ice-free refugia of Scandinavia during the last glaciation, challenging current views on survival and spread of trees as a response to climate changes' (Parducci et al. 2012).

They talk about trees. And now I remember Astrid Cleve von Euler, the first female PhD of natural sciences in Sweden, and how as a young student writing my first essay, I discovered her work and her rejected claims of the ice age survival of Sámi on the Norwegian coast (Cleve von Euler 1936; Öhman 1991). 
I was so thrilled back then, but I never heard of any such ideas again, until now. I start to see humans and animals. Fish. And I remember a film, by a Sámi film maker, that I saw long ago, the first full-length film in Sámi language and based on an old Sámi myth - a Stallo (Stallú) tale. The Stallo, half human, half demon, is evil and cunning, and hates humans for no reason and tries to kill them and eat their flesh, and kidnap children and women. In most narratives, the human ('Sámi' refers to 'human' in Sámi languages) tricks the Stallo into falling into a hole in the ice, or leads him, naked, to a mountain or forest to freeze to death (see Cocq 2008, p. 157). In the film Pathfinder, it is Aigin, a Sámi boy living on the ice and snow whose family has been killed by a band of mean men, and who is being forced to be their pathfinder - also the name of the film — who shows them the way to other fleeing Sámis (Gaup 1987). He manages to trick them and thereby save his people. The Stallo has been beaten again. But what I remember most of all is the overwhelming ice and snow. How could they have lived there? What was the director telling us by showing us all this ice and snow? I remember experiencing $-42^{\circ} \mathrm{C}$ this last winter in Jokkmokk, and I think about my Inuit friends in Greenland, who still live in a region covered by ice, in some parts up to three kilometres thick. And I think, 'maybe we were actually always here', just as the Sámi author Johan Turi states in his 1910 book (Turi 2011). Maybe we too, like our Aboriginal friends in Australia, have been here for at least 60,000 years. Surviving on and by the ice, despite it seeming impossible, until now, when scientists find evidence that certain trees survived. I feel hope. I don't know why. But I feel hopeful. I will reclaim my past. I, who used to hate the cold and snow, will reclaim my understanding of living with and enjoying the ice and snow. I yoik the ice. I yoik the snow. I yoik our past, our present and our future. The Stallo of today is the ongoing depletion of our nature, ever expanding greed for minerals, electricity, energy. They may call it 'development', 'job opportunities' and 'renewable energy resources', but it actually is another invasion by the Stallo. The animals, the reindeer, lose their grazing lands, our fish die, our waters get poisoned, they train shooting at missiles over our heads, and electricity production turns our rivers into death traps for humans and animals. But we won't give up. We survived the ice age; we will not be beaten by the Stallo. We will not perish, we won't vanish. We were always here. We will always remain here.

In the sixteenth century, Gustav Vasa established the Swedish state and began the colonisation of Sápmi (see Öhman 2007). Within this period of enlightenment and through the birth of structuralism as a method to study the other, Sámi people became subject to several scientific studies and, in particular from the nineteenth century, were depicted as being primitive, or closer to nature. These investigations were paralleled with an industrial exploitation of the Sami territories in what was considered as making use of 'dormant' natural resources within the Swedish nation state-hydropower exploitation, mining, and 
forestry. From the 1950s, the region became the arena for state-approved testing of military weapons, including nuclear bombs. In the twenty-first century, as the post-cold war situtation led to cutting down on military spending, these military test bases were turned into commercial test fields where NATO and any interested and well-paying foreign nation may test out missiles and shooting techniques above and on the reindeer grazing lands before making use of them elsewhere in the world. In the public relations imagery of power companies and the military, the area is described as unpopulated, uninhabited wilderness. The Sámi, the humans, just aren't there (see Öhman 2007).

Australia was colonised in 1788, and all that the colonisers had learnt in previous efforts of colonisation would be applied to this new endeavour. Australian Aboriginal peoples also became the object of studies and, like their palerskinned cousins in Sápmi, were assumed to be a vanishing race. Richard Broome speaks of the use of Charles Darwin's theories on evolution and how they was taken up by other theorists to describe human development. Broome states that 'evolutionary theory led to worldwide scientific interest in Australia's Aboriginal peoples, deemed the most 'primitive' of all' (Broome 2010, p. 103). European museums became the recipients of artefacts and remains, grouping together the 'vanishing' people, the Sámi and Indigenous Australians. Aboriginal history became a story of domination and segregation, with the underlying thought being that Aboriginal peoples would eventually cease to be. We were denied the chance to evolve as any other culture does, to make use of the technologies brought by the new inhabitants to build new lives. We are storied as relics of the past, without a right to maintain culture and create hybrid spaces. Our lives became debates about the truth, as is evident in the 'history war': the battle between non-Indigenous academics taking either liberal or conservative views on the writing of history in Australia. Tony Birch, an Indigenous scholar sums it up well:

This cultural war does not involve Indigenous people beyond objectification. Nor does it represent the interests of Indigenous people. The self-styled liberal historians, who have recently engaged in their 'war', believe otherwise and appear to be offended when Indigenous people disagree with them - even within the nominally pluralist environment of the academy. The history war has in fact been a phony war, a brand name and logo to sell books and promote insecure egos as much as it claims to be an engaging and necessary examination of the past (Birch 2007, p. 108).

As Indigenous peoples we need to move beyond objectification. When we travel to our lands of ice and fire our memories return. But it is the discontinuation of the binaries of northern and southern hemisphere and the borrowing of place we take from Pierre Nora that gives us the ability to move beyond objectification. 
Australia and Sweden - unlike Nora's storying of the United States - have yet to become sites of 'plural memories' (Nora 1989, p. 10). To do so they must embrace an instructive history to hold onto national identity. A life history cannot be written under these circumstances, instead we must escape to the place made possible by the work of Pierre Nora, we move 'Between Memory and History: Les lieux de mémoire' (Nora 1989), because we know that the land is a site of memory.

Nora defines a difference between history and memory: 'History, because it is an intellectual and secular production, calls for analysis and criticism. Memory installs remembrance within the sacred; history, always prosaic, releases it again' (Nora 1989, pp. 8-9). He adds that memory is owned by many groups; it can speak of the collective and the individual.

\section{The Embodiment of History}

May-Britt: Two decades after my first embodied encounter with yoik, I walk through the forested lands of the forest Sámi, along the small road from my mother's birth place - nowadays a house empty of inhabitants, which I live in when I come to the area to do interviews for my research project-towards the Lule River. As I walk, inspired by learning about yoiking and vuolles, and recently having followed a short course in yoiking, I try out my own yoik capacity. First it just sounds weird. I can't find my voice. As I continue to walk and try to yoik, I am suddenly attacked by a vuolle. It is an old woman's vuolle surprising me. It is deep in tone, it feels almost ugly and aggressive. It scares me. I stop walking. I stop chanting. At once I realise that the very spot where the old woman's vuolle attacks me is at the crossroads between the old road along the river, at the place of my maternal grandfather's birthplace, and also the home of the last recognised 'real' Sámi in our family. I imagine that it is my grandfather's grandmother, Sigmora (1835-1919), who has spoken to me. She is powerful and somewhat scary. I feel confused. Is it really possible to be attacked by a vuolle? Later the same day I talk to my research colleague, who also knows the Sami world and whose partner and sons are Sámi. I tell her briefly about the incident, saying that a vuolle came over me. I somehow expect her to dismiss my feeling. Yoik attacks aren't something I can really speak about within the academic world and be taken seriously. When yoiking is discussed in academia, it is as a study object, something to be analysed, something that can be dissected. But instead she asks: 'What kind of yoik was it?'

Again, I am shocked. I am stunned by the recognition of my experience. I thought we would laugh at it together and dismiss it as something funny but not real. So I hesitate. Then I answer, 'I don't know', and quickly change subject. 
I feel I need to contemplate what has happened. I don't have the words to explain it, even to myself. But in all cases, even though I might not be ready just yet, I have heard a-my own?- Sámi voice breaking through. When I am ready I will yoik again. I think Sigmora wants me to be proud and trust myself.

Phenomenologist Maurice Merleau-Ponty, in speaking of his homeland France, said that 'history takes still more from those who have lost everything, and gives yet more to those who have taken everything. For its sweeping judgements acquit the unjust and dismiss the pleas of their victims. History never confesses' (Merleau-Ponty 1964, p. 4). As scholars using autobiography or life writing, we find shared methodologies to tell stories. Through embodiment comes a new identity, shared and understood through the reworking of European philosophical traditions.

The nature of our academic research has taken both authors close to our ancestral lands. In such incidents we were overtaken with a need to write stories of inquiry. These episodes introduce a memory and a change in identity. May-Britt, in her urge to yoik, illustrates a deeper embodied need to use her ancestral traditions to yoik the hillside and the forest, to recognise the landscape as a memory place, a place of decolonisation. Nora described an era of historiography in an 'epistemological age', where historiography becomes a site for memory (Nora 1989). We can then embody these ancestral memories and use them to construct stories. We re-learn a set of knowledges and discourses, our habits change. We see a world that is colonised, but we also see under it a site that still holds its memory and can tell its stories to those who can listen. Frances experienced this phenomenon when travelling through desert country on her way back to her city workplace, a structure that consists of small offices along a corridor which can be described figuratively as a workplace of silos. Silos, in the literal and non-figurative sense, are large cylindrical buildings that store grain. To 'whitewash' was a term used throughout the 'history wars' in Australia to denote a re-storying or censorship by the dominant, in this case white, culture. Whitewash in its literal sense is a type of low-cost lime-based paint. The author, in the passage below, uses the literary method of metaphor to draw parallels but also to speak of the joy in knowing her desert origins and the solace that it provides:

In the land of silos, every year you get new information to whitewash your sense of knowing in a way that denies you the truth as you sit in a world dominated by western science. You believe that like the ones who paint the silos white you make your own knowledge strong, you are re-imagining your own dominance on the landscape where your truth must be loud to affirm your own survival. In the land of solace you only have to listen to yourself and the truth that comes from being to survive (Wyld 2011, p.66). 
If history will not confess, then sites of memory must have an equally loud voice to bring balance. We are turning again to Merleau-Ponty and his recognition that 'the main concern of our time is going to reconcile the old world and the new' (Merleau-Ponty 1964, p. 4). As collaborators from different hemispheres, we have learnt our commonalities and how we had to learn new sets of knowledges to reconcile old and new theories within our academic work. To meet this goal, we use the work of Nora and his 'new genre, for a new age of historical consciousness' (Nora 1984, p. 4). We use story and an understanding that our histories are embodied within us, we use memory because the past refuses to be forgotten.

Frances: I perch like a bird on my balcony on the 23rd-floor room of an Auckland hotel. I am in Auckland for an Indigenous research methodology conference. This is a culturally safe space that acknowledges the need to use multiple disciplines that has Indigenous knowledge at its base. It is timeless, incongruous with the discipline of history. Indigenous voices are here, there was even a yoik delivered during the cultural events. I presented today, choosing to tell a story of motherhood, not the documented story of my family history, although I did choose to include an image depicting but not naming my aunt and grandmother. In question time, someone asked how my grandmother got home. I paused before answering, telling the questioner that my answer will sound like the title of a book and film, because it is. Then I went on to say that I have already written about the impact this has had on my working life (Somerville, Somerville and Wyld, 2010), and the objectification that nonIndigenous colleagues have committed when using the film in teaching without having conversations with me, without acknowledging the connection. After the presentation, an Indigenous elder came to me, kissed me, and whispered, 'you told my story too'. I perch on the balcony, like a bird wanting to fly back to its homeland. I watch parts of the film on YouTube. It is pure Hollywood, it is dramaticised and has been criticised in the media, and my goal now is to find another perch from which to teach Indigenous content. Now on my home campus a week later I am in the library researching European scholars once again. I want to look into the idea of auratic perception used by German Jewish scholar Walter Benjamin (Benjamin 2005). I want to teach cultural studies to students in a way that acknowledges other people who believe in a connection to place, and that it isn't just within an Indigenous worldview. I find the book I want, and above it on another shelf is the book penned by my aunt poking out amongst other books, as if someone had looked at it and not put it back properly. I take it and in re-reading am reminded that it is a gentle re-telling of history. It tells me that we are forced within this academic space to become critical, to be in crisis - as the etymology of critical describes - to be in a diseased place. This is not a way to be, it is not the ontology of Indigenous peoples. In reading 
my grandmother's story, written by my aunt, I am reminded that Martu women are often 'quiet' and 'dignified' (Garimara 1996, p.76) and I wonder if this is because we know how to carry a sense of history within us?

\section{Conclusion}

As authors, historians and Indigenous scholars we are in support of the idea of ego-histoire because it fits an Indigenous worldview; we challenge the production of the winners' Hi-Story of the current existing nation states. We argue for the idea of ego-histoire as it can bring forward a so-far silenced history, not available in the documents in the coloniser's archives. Together we dare to rely on our Indigenous traditions. We are daring to recognise stories and memories coming to us - not through coloniser's archives and archaeological findings only, but through our embodied encounters with myths, landscapes and memories passed down - as well as our own traditions on how our history is told and retold. Ego-histoire asks the historian to look back at themselves and to write the self into their work. We also support Nora's work into lieux de mémoire because it fits with the Indigenous connection to land. Our title claimed a binary of hemispheres but our collaboration is only made possible because of a belief in a single sphere that is currently colonised by dominant cultures, a sphere that wants Indigenous people to remain primitive, to vanish, and fade away as exotic museum relics. We are historians and academics, and we create a new vision of history, which could be on display in museums. The history we need to write and transmit in our present is of our own lives and circumstances. We are voices that want to be heard after decades of being objects on the dissecting plate of the winning historians' gaze where our stories were considered as curiosities. Our lands of fire and ice are returned to us through stories, alongside winners' side historians who are brave enough to write themselves into their own work, and challenge Hi-Story. We started our work with a prelude, should we end it with an epilogue? No, because the story doesn't end, it is the Möbius strip folding back on itself creating what Indigenous people have always had: a sense of timelessness, of always being here, and the determination to always remain here. 


\section{References}

Arbon, V 2008, Arlathirnda Ngurkarnda Ityirnda: Being - knowing - doing: De-colonising Indigenous tertiary education, Post Pressed, Teneriffe.

Anderson, I 2003, 'Black Bits, White Bits', in M Grossman (ed.), Blacklines: Contemporary critical writing by Indigenous Australians, Melbourne University Press, Melbourne, pp. 43-51.

Archibald, J 2008, Indigenous Storywork: Educating the heart, mind, body, and spirit, University of British Columbia Press, Vancouver.

Benjamin, A 2005, Walter Benjamin and History, Continuum, London.

Birch, T 2007, “"The Invisible Fire": Indigenous sovereignty, history and responsibility', in A Moreton-Robinson (ed.), Sovereign Subjects: Indigenous sovereignty matters, Allen \& Unwin, Sydney, pp. 105-117.

Broome, R 2010, Aboriginal Australians: A history since 1788, fourth edition, Allen \& Unwin, Crows Nest.

Cleve von Euler, A 1936, Komsakulturens Ålder, Lindesberg.

Cocq, C 2008, Revoicing Sámi Narratives: North Sámi storytelling at the turn of the twentieth century. unpublished $\mathrm{PhD}$ thesis, Umeå Universitet. Available at: http://urn.kb.se/resolve?urn=urn:nbn:se:umu:diva-1598.

Fanon, F 1971, The Wretched of the Earth, Penguin, London.

Garimara, D P 1996, Follow the Rabbit-Proof Fence, University of Queensland Press, St Lucia.

Gaup, N 1987, Pathfinder, Norwegian Film Institute, Norway.

Haraway D 1991a, 'A Cyborg Manifesto: Science, technology and socialistfeminism in the late twentieth century', in D Haraway (ed.), Simians, Cyborgs and Women: The reinvention of nature, Routledge, London and New York, pp. 149-181.

Haraway, D 1991b, 'Situated Knowledges: The science question in feminism and the privilege of partial perspective', in D Haraway (ed.), Simians, Cyborgs and Women: The reinvention of nature, Routledge, London and New York, pp. 183-201.

Kovach, M 2010, Indigenous Methodologies: Characteristics, conversations, and contexts, University of Toronto Press, Toronto. 
Ngapartji Ngapartji, In Turn, In Turn: Ego-histoire, Europe and Indigenous Australia

Martin, K 2008, Please Knock Before You Enter: Aboriginal regulation of outsiders and the implications for researchers, Post Pressed, Teneriffe, QLD.

Merleau-Ponty, M 1964, Signs, Northwest University Press, Evanston.

Moreton-Robinson, A 2009, Talkin' Up to the White Woman: Indigenous women and feminism, University of Queensland Press, St Lucia.

Nora, P 1989, 'Between Memory and History: Les lieux de mémoire', Representations, no. 26, pp. 7-24.

Öhman, M-B, 2010, 'Being May-Britt Öhman: Or, reflections on my own colonized mind regarding hydropower constructions in Sápmi', in Elovaara, Sefyrin, Öhman \& Björkman (eds), Travelling Thoughtfulness: Feminist Technoscience Stories, Department of Informatics, Umeå University, Umeå, pp. 262-292.

Öhman, M-B 2007, ‘Taming Exotic Beauties: Swedish Hydropower Constructions in Tanzania in the Era of Development Assistance, 1960s-1990s', Stockholm Papers in the History and Philosophy of Technology, Royal Institute of Technology, Stockholm. Available at: http://kth.diva-portal.org/smash/get/ diva2:12267/FULLTEXT01.

Öhman, M-B, 1991, 'De Första Naturvetenskapskvinnorna vid Uppsala Universitet', unpublished undergraduate essay, Department of History of Science and Ideas, Uppsala University.

Ojala, C 2009, 'Sámi Prehistories: The politics of archaeology and identity in northernmost Europe', Occasional Papers in Archaeology no. 47, Department of Archaeology and Ancient History, Uppsala.

Parducci L, T Jorgensen, M M Tollefsrud, E Elverland, T Alm \& S L Fontana 2012, 'Glacial Survival of Boreal Trees in Northern Scandinavia', Science, vol. 335, no. 6072, pp. 1083-1086.

Peters-Little, F 2010, 'Introduction', in F Peters-Little, A Curthoys \& J Docker (eds), Passionate Histories: Myth, Memory and Indigenous Australians, ANU E Press, Canberra, pp. 1-6

Popkin, J D 1996, 'Ego-Histoire and Beyond: Contemporary French historianautobiographers', French Historical Studies, vol. 19, no. 4, pp. 1139-1167.

Smith, L T 2005, 'On Tricky Ground: Researching the native in the age of reason', in N Denzin \& Y Lincoln (eds), Sage Handbook of Qualitative Research, Sage, London, pp. 85-107.

Smith, L T 1999, Decolonizing Methodologies: Research and Indigenous peoples, University of Otago Press, Dunedin. 
Somby, A 1996, 'Joik and the Theory of Knowledge', in M Haavelsrud (ed.), Kunnskap og Utvikling, Universitetet i Tromsø, Tromsø.

Somerville, C, K Somerville \& F Wyld 2010, 'Martu Storytellers: Aboriginal narratives within the academy', The Australian Journal of Indigenous Education, vol. 39, supplement, pp. 96-101.

Stoor, K 2007, Juoiganmuitalusat - Jojkberättelser: En studie av jojkens narrativa egenskaper, unpublished $\mathrm{PhD}$ thesis, Umeå University. Available at: http://urn.kb.se/resolve?urn=urn:nbn:se:umu:diva-1323.

Turi, J 2011, An Account of the Sámi, Nordic Studies Press, Chicago.

Watson, I 2007, 'Settled and Unsettled Spaces: Are we free to roam?' in A Moreton-Robinson (ed.), Sovereign Subjects: Indigenous sovereignty matters, Allen \& Unwin, Sydney, pp. 15-32.

Wyld, F 2011, 'In the Land of Silos', Journal of Australian Indigenous Issues, vol. 14 no. 1 , pp. 63-66. 
This text taken from Ngapartji Ngpartji: In turn in turn:

Ego-histoire, Europe and Indigenous Australia

Edited by Vanessa Castejon, Anna Cole, Oliver Haag and Karen Hughes,

published 2014 by ANU Press, The Australian National University, Canberra, Australia. 